\title{
Catalase Induced by All-Trans Retinoic Acid Is Involved in Antiproliferation of 36B10 Cells
}

\author{
Woo-Yoon Park, M.D.* and Jae-Ran Yu, M.D. ${ }^{\dagger}$ \\ *Department of Radiation Oncology, Chungbuk National University College of Medicine, Cheongju, \\ ${ }^{\dagger}$ Department of Environmental and Tropical Medicine, \\ Konkuk University College of Medicine, Chungju, Korea
}

\begin{abstract}
Purpose: All-trans retinoic acid (ATRA) has antiproliferative effects against brain tumor cells. Recently, ATRA has been reported to induce catalase. We investigated whether catalase induction by ATRA is associated with its antiproliferative effects.

Materials and Methods: 36B10 cells were exposed to $0 \sim 50 \mu \mathrm{M}$ ATRA for 24 or 48 hours and mRNA, protein, and activity of catalase were measured. Reactive oxygen species (ROS) were measured using $2^{\prime}, 7^{\prime}$-dichlorofluorescin diacetate. A clonogenic assay was used to confirm the cytotoxic effect.

Results: The mRNA, protein, and activity of catalase were found to increase in a concentration- and incubationtime-dependent manner. The increase in catalase activity induced by ATRA was decreased by the addition of 3-amino-1,2,4-triazole (ATZ). ROS was also increased with ATRA and decreased by the addition of ATZ. The decrease in cell survival induced by ATRA was partly rescued by ATZ.

Conclusion: Catalase induction by ATRA is involved in ROS overproduction and thus inhibits the proliferation of 36B10 cells.
\end{abstract}

Key Words: All-trans retinoic acid, Catalase, Reactive oxygen species

\section{Introduction}

Retinoids are a group of natural and synthetic derivatives of vitamin A. Many animal and clinical studies have provided strong support for the use of retinoids in cancer therapy and prevention. In fact, all-trans retinoic acid (ATRA) is currently used for the treatment of acute promyelocytic leukemia. Also, ATRA has antiproliferative effects against some animal and human brain tumor cells, ${ }^{1,2)}$ and has been applied as a clinical treatment for malignant glioma. ${ }^{3 \sim 5)}$ However, the treatment results with ATRA alone have been uncertain, making it necessary to improve the understanding of how it inhibits proliferation. ATRA exerts its effects on cell growth and differentiation by binding to retinoic acid receptors (RARs).

Submitted June 4, 2010, accepted Ocotber 11, 2010

Reprint requests to Woo-Yoon Park, M.D., Department of Radiation Oncology, Chungbuk National University College of Medicine, Seongbong-ro, Cheongju 361-763, Korea

Tel: 043)269-6376, Fax: 043)269-6387

E-mail: wynpark@chungbuk.ac.kr
RARs heterodimerize with retinoid X receptors (RXRs) and induce gene transcription by binding to retinoic acid response elements located in the regulatory regions of retinoid responsive genes. Also, ATRA can bind to RXRs through isomerization to 9-cis retinoic acid. ${ }^{6}$ RXRs form heterodimers not only with RARs but also with other ligand-dependent members of the nuclear receptor family, including thyroid hormone receptors, vitamin $\mathrm{D}$ receptor, liver $\mathrm{X}$ receptor, and peroxisome-proliferator-activated receptors (PPARs). ${ }^{7,8)} \mathrm{RXR} /$ PPAR heterodimers act by binding to peroxisomal proliferator response elements (PPREs). Also, RXR homodimers can selectively bind to functional PPREs. A PPRE was identified in the rat catalase promoter, and catalase was increased by an RXR ligand. ${ }^{9)}$ Catalase is expressed mainly in peroxisomes, where under basal condition, exerts a major role in the cleaning of $\mathrm{H}_{2} \mathrm{O}_{2}$ generated by the peroxisomal $\beta$-oxidation. Also, catalase activity may be enhanced by toxic concentrations of $\mathrm{H}_{2} \mathrm{O}_{2}$ and oxidative stresses. ${ }^{10)}$ It has been shown that catalase induction is mediated via increased reactive oxygen species (ROS) production induced by ATRA. ${ }^{11)}$ On the 
other hand, ATRA can modulate catalase activity by a mechanism independent of ROS production and protein/mRNA expression. ${ }^{12)}$ Normally net cell redox state and the antioxidant enzymes should be well balanced. Altered antioxidant levels may cause detrimental effect on the cells. Here we investigated whether the increase in catalase induced by ATRA is associated with the antiproliferative effects of ATRA.

\section{Materials and Methods}

\section{Cells and culture condition}

Ethyl-nitrosourea-induced 36B10 rat astrocytoma cells (a gift from Dr. Larry Oberley, University of Iowa, USA) were grown in DMEM containing $10 \%$ fetal bovine serum supplemented with $100 \mathrm{IU} / \mathrm{mL}$ penicillin and $100 \mathrm{~g} / \mathrm{mL}$ streptomycin. The cells were kept in a humidified atmosphere containing $5 \%$ carbon dioxide at $37^{\circ} \mathrm{C}$, and passaged every 3 days by trypsinization. The $36 \mathrm{~B} 10$ cells used for the described experiments were between passages 8 and 25. ATRA was diluted from stock solution resolved in dimethyl sulfoximide (DMSO). The final concentration of DMSO in the medium was $<0.1 \%$. All culture reagents were purchased from Invitrogen (Carlsbad, CA, USA).

\section{Clonogenic assay}

The optimal number of cells for colony counting was seeded onto $60-\mathrm{mm}$ dishes. On the next day the cells were refreshed with new medium containing drugs and incubated further until the colonies were observed. The cells were stained with $0.1 \%$ crystal violet solution, and the number of colonies comprising at least 50 cells was counted. The surviving fraction (SF) was calculated as the ratio of the plating efficiency between treated and control dishes.

\section{Protein extraction for Western blotting and catalase activity assay}

Cell proteins were obtained by rinsing the cells three times with phosphate-buffered saline (PBS, $\mathrm{pH}$ 7.2), scraping the cells from the culture flasks with a rubber policeman, and centrifuging at $1,000 \mathrm{~g}$ for 10 minutes. The PBS was then removed, and the cells were resuspended with $1 \mathrm{~mL}$ of PBS in Eppendorf tubes and centrifuged for 2 min. The PBS was again removed and the pellets were kept frozen at $80^{\circ} \mathrm{C}$ until use. Just before analysis, the cell pellets were resuspended in one volume of $50 \mathrm{mM}$ potassium phosphate buffer $(\mathrm{pH} 7.85)$ and sonicated on ice three times for $10 \mathrm{~s}$ using a cell sonicator (Vibra, Sonics \& Materials, Newtown, CT, USA). The protein concentration was determined using the Bradford method with bovine serum albumin as a standard.

\section{Western blot analysis}

Proteins was denatured in 1 volume of sample buffer containing $62.5 \mathrm{mM}$ Tris- $\mathrm{HCl}(\mathrm{pH}$ 6.8), $10 \%$ glycerol, $2 \%$ sodium dodecyl sulfate (SDS), $5 \%$ mercaptoethanol (v/v), and two or three drops of saturated bromophenol blue solution at $100^{\circ} \mathrm{C}$ for 3 minutes. The proteins were separated in a $12.5 \%$ denaturing polyacrylamide gel by electrophoresis and then transferred onto nitrocellulose membranes at $100 \mathrm{~V}$ for 1 hour on ice at $4^{\circ} \mathrm{C}$. The blots were then blocked in $4 \%$ dry milk in TTBS (0.02 M Tris buffer, $\mathrm{pH} 7.0$ and $0.5 \%$ Tween 20) at room temperature for 2 hours and incubated with primary antibody $(1: 1,000)$ in TTBS at $4^{\circ} \mathrm{C}$ overnight. After washing three times with TTBS, the blots were incubated with secondary antibody $(1: 10,000)$. After washing three times, the chemiluminescence of the blots was visualized. The antibody for catalase was purchased from Athens Research and Technologies (Athens, GA, USA).

\section{Northern blot analysis}

Total RNA was isolated using the acid guanidinium thiocyanate-phenol-chloroform extraction method using TRIzol (Gibco, Gaithersburg, MD, USA), and the concentration of RNA was determined spectrophotometrically at $260 \mathrm{~nm}$. Ten micrograms of RNA was denatured and loaded onto a $1.2 \%$ agarose gel containing $2.5 \%$ formaldehyde and $1 \times$ MOPS [3-(N-morpholino) propanesulfonic acid]. The gel was electrophoresed at a constant voltage of $80 \mathrm{~V}$ for 2 hours. Each gel was photographed to check the loading quality and rinsed twice in $20 \times$ SSC $(1 \times$ SSC corresponds to $0.15 \mathrm{M}$ sodium chloride and $0.15 \mathrm{M}$ sodium citrate, $\mathrm{pH}$ 7.0) for 15 minutes, and the RNA was transferred to a nylon membrane (Gene Screen, New England Nuclear, Boston, MA, USA) in $10 \times$ SSC by capillary transfer. The blotted RNA samples were fixed to the membrane using a UV cross-linker (Stratalinker 1800, Stratagene, LaJolla, CA, USA). Blots were then prehybridized at $42^{\circ} \mathrm{C}$ for 4 hours in a hybridization oven (Personal Hyb, 
Stratagene) in a buffer containing $50 \%$ formamide, $5 \times$ SSPE $(1 \times$ SSPE corresponds to $0.15 \mathrm{M}$ sodium chloride and $10 \mathrm{mM}$ sodium phosphate, $5 \mathrm{mM}$ EDTA, $\mathrm{pH}$ 7.0), $10 \%$ dextran sulfate, $10 \times$ Denhardt's solution, $1 \%$ SDS, and $150 \mu \mathrm{g} / \mathrm{mL}$ sheared denatured salmon-sperm DNA. The blots were then hybridized at $42^{\circ} \mathrm{C}$ for $16 \sim 24$ hours in a buffer containing $50 \%$ formamide, $5 \times$ SSPE, $10 \%$ dextran sulfate, $10 \times$ Denhardt's solution, $1 \%$ SDS, $150 \mu \mathrm{g} / \mathrm{mL}$ sheared denatured salmonsperm DNA, and $\left[{ }^{32} \mathrm{P}\right]$-labeled probe. The cDNA probes were labeled with $\left[{ }^{32} \mathrm{P}\right] \mathrm{dCTP}$ (New England Nuclear) by the random primer extension method using a random primer DNA labeling kit (Boehringer Mannheim, Mannheim, Germany). After hybridization, the membranes were washed twice in $2 \times$ SSPE and $0.5 \%$ SDS for 15 minutes each at room temperature, and then twice in $0.1 \times \mathrm{SSPE}$ at $65^{\circ} \mathrm{C}$ for 15 minutes each. The membranes were then wrapped in Saran plastic wrap, and autoradiography was performed using Kodak X-OMAT film at $-70^{\circ} \mathrm{C}$ for $1 \sim 5$ days depending on the signal strength. After hybridization, the cDNA probe was stripped by boiling the membrane twice in $0.1 \%$ SDS for 15 minutes each. Membranes were reprobed using a housekeeping gene, glyceraldehyde-3-phosphate dehydrogenase (GAPDH), which served as a control to ensure equal loading of the gel. Autographs were quantified by densitometry (Alpha Imager 2000, Alpha Innotech, San Leandro, CA, USA). The optical density (OD) of each probe was normalized by dividing the measured signal by the OD of GAPDH. The induction of each gene was expressed as the increase in mRNA signal measured in the ATRA-treated cells relative to control cells. Each experiment was performed a minimum of three times, and representative blots are shown here.

\section{Catalase activity assay}

Catalase activity was assayed as described by Beers and Sizer $^{13)}$ In brief, $200 \mu \mathrm{g}$ of protein was added to a cuvette containing $50 \mathrm{mM}$ phosphate buffer ( $\mathrm{pH}$ 7.8), and hydrogen peroxide $\left(\mathrm{H}_{2} \mathrm{O}_{2}\right)$ was added to a final concentration of $10 \mathrm{mM}$. The disappearance of $\mathrm{H}_{2} \mathrm{O}_{2}$-as determined by its absorbance at $240 \mathrm{~nm}$-was measured at 30-s intervals for 1 minute. Activity was quantified as units per gram of protein.

\section{ROS measurement}

Cells were seeded in 96-well plates (Nunc, Roskilde,
Denmark) at a density of $1 \times 10^{4}$ cells/well, and the next day the medium was replaced with a new one containing ATRA at a defined concentration. After maintaining the solution for 48 hours, the cells were washed with PBS twice and incubated with $40 \mu \mathrm{M}$ 2',7'-dichlorofluorescin diacetate (DCF-DA) (Molecular Probes, Eugene, OR, USA) at $37^{\circ} \mathrm{C}$ for 30 minutes. The cells were then again washed twice with PBS, lysed with $0.5 \%$ SDS, and the fluorescence was measured with a fluorescence reader using excitation at $485 \mathrm{~nm}$ and measuring the emission at $530 \mathrm{~nm}^{14,15)}$

\section{Statistical analysis}

Data are expressed as mean and SD values. Differences were analyzed by Student's t-test, and were considered to be significant when $\mathrm{p}<0.05$.

\section{Results}

\section{Expression of catalase protein by ATRA}

To investigate whether catalase protein is increased by ATRA, 36B10 cells were supplemented with $0 \sim 50 \mu \mathrm{M}$ ATRA for 24 or 48 hours. Catalase protein was increased in a dose- and time-dependent manner (Fig. 1). It was 1.9-fold higher than that of control for incubation with $50 \mu \mathrm{M}$ ATRA for 48 hours.

\section{Expression of catalase mRNA by ATRA}

To investigate whether the mRNA of catalase is induced by ATRA, 36B10 cells were incubated with $50 \mu \mathrm{M}$ ATRA for 6 , 12,24 , or 48 hours, and the mRNA expression was analyzed by Northern blotting. Catalase mRNA increased with the incubation time, with its level being about 2-fold higher after 24 and 48 hours (Fig. 2). Catalase mRNA also increased with the dose of ATRA $(10,25$, or $50 \mu \mathrm{M}$ for 48 hours), with its level after incubation with $50 \mu \mathrm{M}$ ATRA for 48 hours being about 2-fold higher than that of control (Fig. 3). This suggests that the increased catalase protein expression is due to the induction of increased catalase mRNA.

\section{Catalase activity by ATRA}

To investigate whether the increase in catalase protein is related to its activity, 36B10 cells were incubated without ATRA or with $10 \mu \mathrm{M}$ ATRA for 48 hours, and catalase 
A
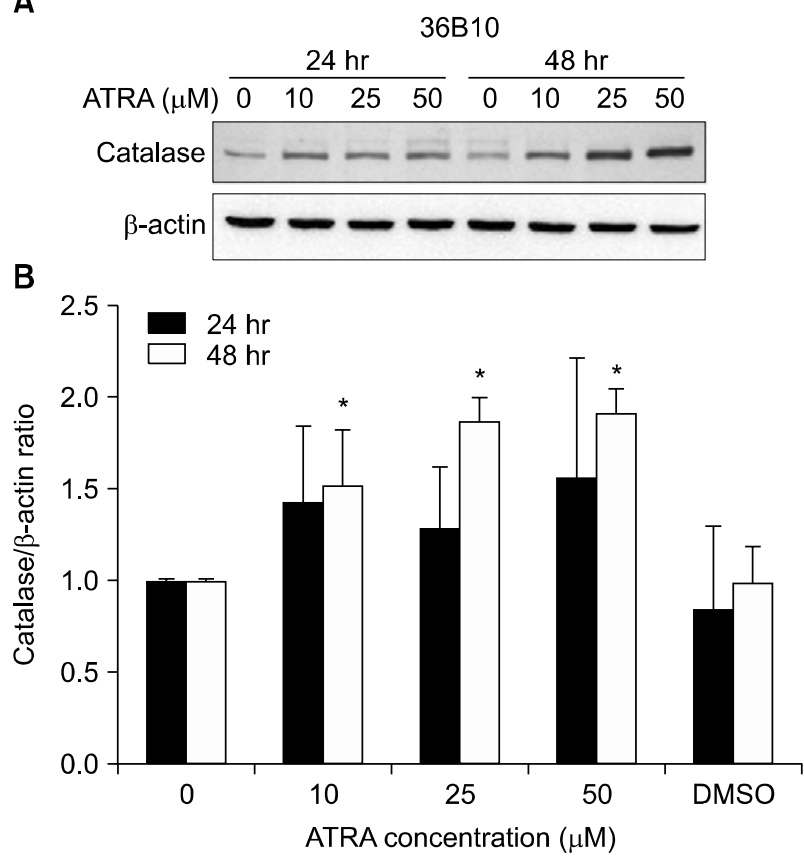

Fig. 1. Expression of catalase protein induced by all-trans retinoic acid (ATRA). (A) 36B10 cells were supplemented with 0 $50 \mu \mathrm{M}$ ATRA for $24 \mathrm{hr}$ or $48 \mathrm{hr}$, and Western blotting was performed for catalase. Catalase protein increased in a doseand time-dependent manner. (B) The levels of catalase and $\beta$ -actin were quantitated by densitometric analysis and the catalase/actin ratio was determined. Data are mean and SD values of three independent experiments. ${ }^{*} \mathrm{p}<0.05$.

activity was measured. We used $10 \mu \mathrm{M}$ for further experiments to see the effect in more similar condition to physiologic one. Catalase activity was about 1.4-fold higher than that of control (Fig. 4). To test whether the increased catalase activity induced by ATRA is decreased by a chemical inhibitor, 3-amino-1,2,4-triazole (ATZ; Sigma, St. Louis, MO, USA), 36B10 cells were incubated with $10 \mu \mathrm{M}$ ATRA and 10 mM ATZ simultaneously. The addition of ATZ decreased the catalase activity.

\section{ROS change by ATRA}

Catalase catalyzes the conversion of $\mathrm{H}_{2} \mathrm{O}_{2}$ into water and oxygen. ${ }^{16)}$ To assess whether the increase in catalase induced by ATRA contributes to ROS scavenging, ROS levels were measured using DCFH-DA as a probe. Contrary to our expectation, treatment of 36B10 cells with $10 \mu \mathrm{M}$ ATRA for 48 hours increased ROS production 1.5-fold relative to control. The addition of ATZ decreased ROS in a dose-dependent manner (Fig. 5). This indicates that the increase in catalase
A

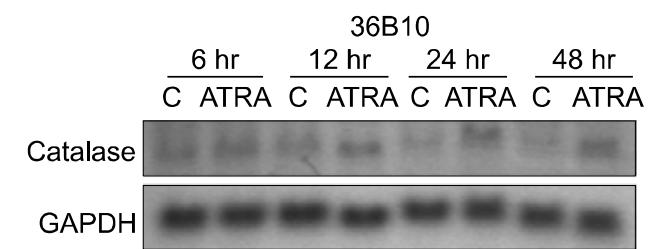

B

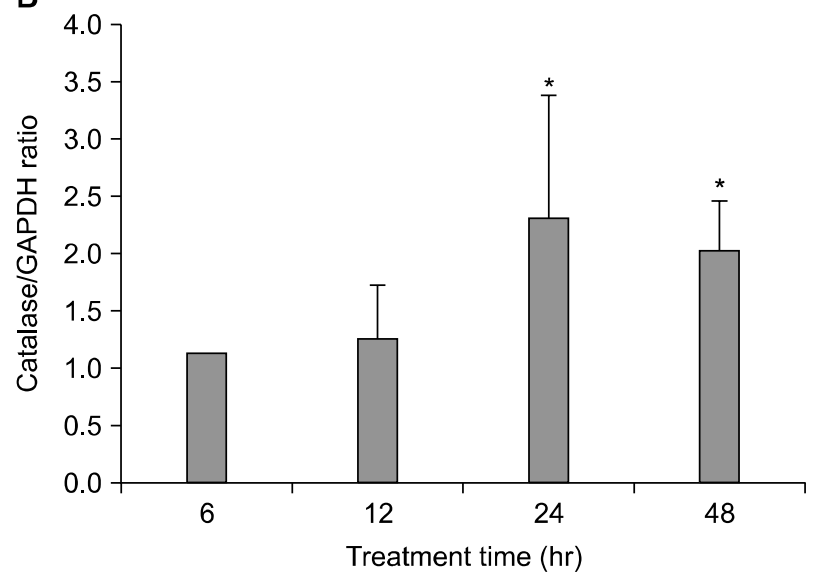

Fig. 2. Expression of catalase mRNA according to the incubation time of all-trans retinoic acid (ATRA). (A) 36B10 cells were incubated with $50 \mu \mathrm{M}$ ATRA for $6,12,24$, or 48 hours, and Northern blotting was performed. Catalase mRNA increased with the incubation time. (B) The levels of catalase and GAPDH were quantitated by densitometric analysis and the catalase/GAPDH ratio was determined. Data are mean and $\mathrm{SD}$ values of three independent experiments. ${ }^{*} \mathrm{p}<0.05$.

induced by ATRA does not contribute to ROS scavenging but is involved in ROS production in 36B10 cells.

\section{Cell-survival change by ATRA}

ATRA exerts antiproliferative effects in various cells. ${ }^{1,2,17)}$ To investigate the effects of catalase on cell proliferation, clonogenic cell survival was measured after treatment with ATRA with or without ATZ. The SF for treatment with $10 \mu \mathrm{M}$ ATRA alone was 0.5 , and this was increased to 0.8 by the addition of $10 \mathrm{mM}$ ATZ (Fig. 6). This indicates that abnormally increased catalase is harmful to $36 \mathrm{~B} 10$ cells and is related to the antiproliferative effects of ATRA, whereas ATZ alone does not affect cell survival.

\section{Discussion and Conclusion}

The clinical efficacy of ATRA has been questioned due to its growth inhibitory effects being lower in human glioma cells than in rat glioma cells. However, a clinical role for 
A

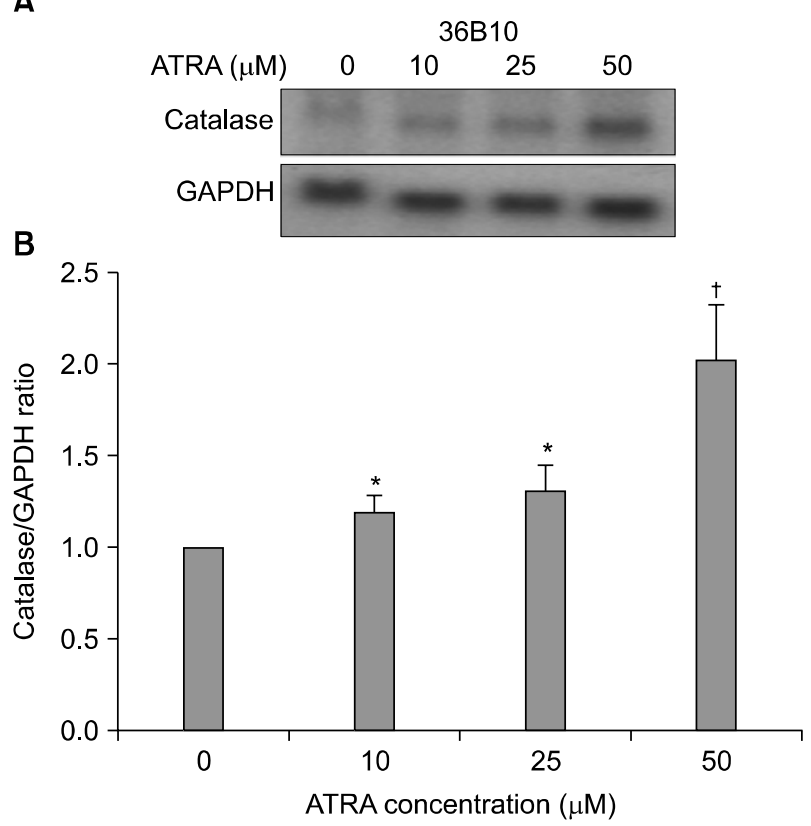

Fig. 3. Expression of catalase mRNA according to the dose of all-trans retinoic acid (ATRA). (A) $36 \mathrm{~B} 10$ cells were incubated with $0,10,25$, or $50 \mu \mathrm{M}$ ATRA for 48 hours, and Northern blotting was performed. Catalase mRNA increased with the ATRA dose. (B) The levels of catalase and GAPDH were quantitated by densitometric analysis and the catalase/GAPDH ratio was determined. Data are mean and SD values of three independent experiments. ${ }^{*} \mathrm{p}<0.05,{ }^{\dagger} \mathrm{p}<0.005$.

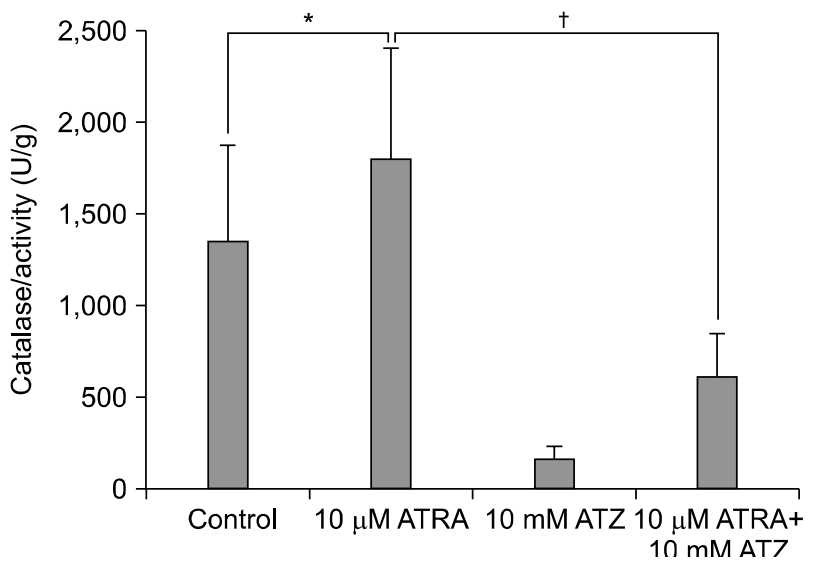

Fig. 4. Catalase activity change induced by all-trans retinoic acid (ATRA). 36B10 cells were incubated without ATRA or with $10 \mu \mathrm{M}$ ATRA for 48 hours, and catalase activity was measured. Catalase activity increased with ATRA, and this was decreased by 3-amino-1,2,4-triazole (ATZ). Activity was quantified in units per gram of protein $(\mathrm{U} / \mathrm{g})$, and is expressed here as mean and SD values of four independent experiments. ${ }^{*} \mathrm{p}<0.05,{ }^{\dagger} \mathrm{p}<0.005$.

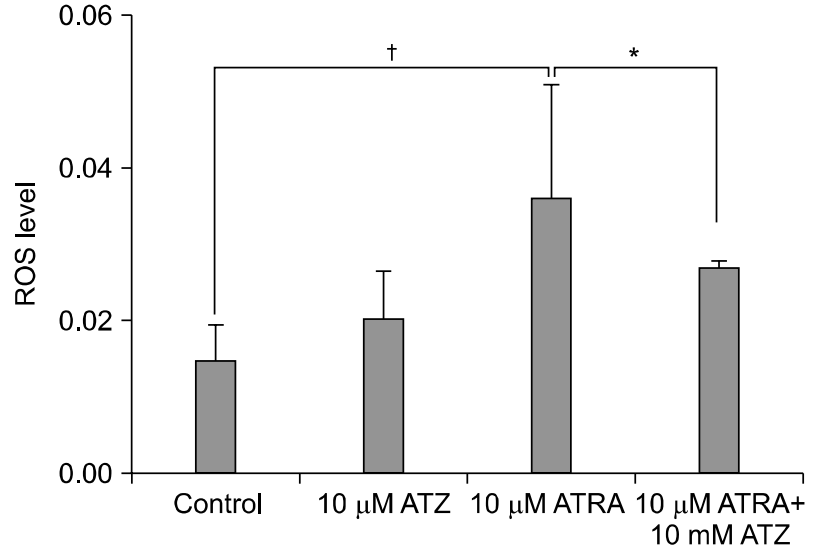

Fig. 5. Reactive oxygen species (ROS) change induced by all-trans retinoic acid (ATRA). 36B10 cells were treated with 10 $\mu \mathrm{M}$ ATRA for 48 hours, and the ROS change was measured using DCF-DA as a probe. ROS production increased with ATRA, and this was decreased by the addition of 3amino-1,2,4-triazole (ATZ). Data are mean and SD values of four independent experiments. ${ }^{*} \mathrm{p}<0.05,{ }^{\dagger} \mathrm{p}<0.005$.

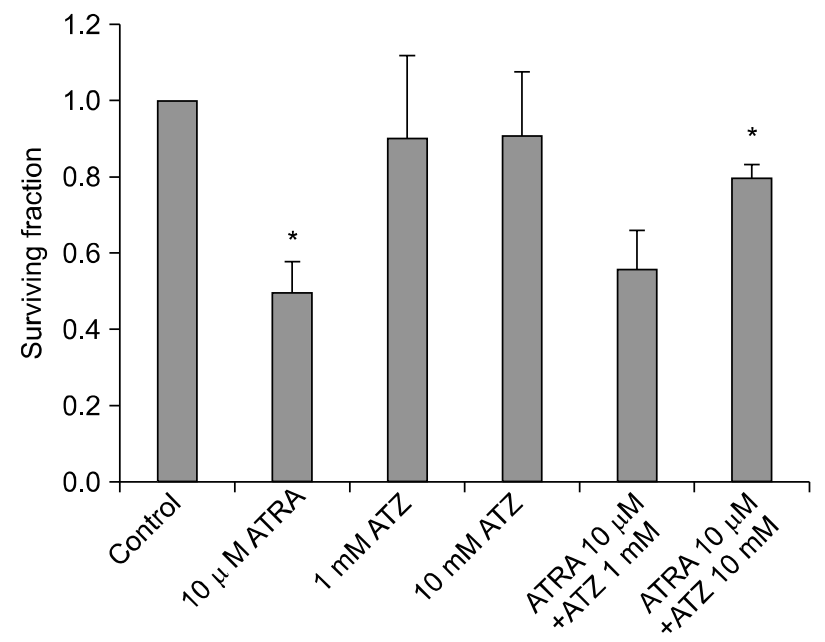

Fig. 6. Cell-survival change induced by all-trans retinoic acid (ATRA). 36B10 cells were treated with ATRA without 3amino-1,2,4-triazole (ATZ) or with ATZ, and clonogenic cell survival was measured. The surviving fraction with $10 \mu \mathrm{M}$ ATRA alone was 0.5 , and this was increased to 0.8 by the addition of $10 \mathrm{mM} \mathrm{ATZ.}{ }^{*} \mathrm{p}<0.05$ relative to control.

ATRA remains possible since it is effective in primary cultured human glioma cells. ${ }^{18)}$ Glioma cell lines have shown various range of growth inhibition at pharmacologically achievable concentration $(1 \mu \mathrm{M})$ of ATRA. ${ }^{2,19,20)}$ In this study the surviving fraction of $36 \mathrm{~B} 10$ cells at $1 \mu \mathrm{M}$ of ATRA was negligible (data not shown). Thus, we focused on the higher dose of ATRA to study the antiproliferative mechanism of ATRA. ATRA at a high concentration increases ROS produc- 
tion, and this has been suggested as one of the mechanisms underlying its antiproliferative effects. ${ }^{21)}$ Some retinoids induce the generation of $\operatorname{ROS}^{22)}$ and lipid peroxidation, which has a negative correlation with cell proliferation. The mechanism by which retinoids induce ROS generation is not known well. However, propagation of radical chain reactions was suggested. $^{23)}$ It has been shown that catalase induction is mediated via increased ROS production induced by ATRA. ${ }^{11)}$ Catalase resides in the peroxisomes and catalyzes the dismutation of $\mathrm{H}_{2} \mathrm{O}_{2}$ into oxygen and water. The induction of catalase by ATRA has been reported in renal mesangial, glioblastoma, and neuronal cells. ${ }^{11)}$ On the other hand, ATRA can modulate catalase activity by a mechanism independent of ROS production and protein/mRNA expression. ${ }^{12)}$ Therefore, the mechanism of increased catalase activity induced by ATRA varies with the cell type, and so further research is needed.

In the present study, ATRA increased ROS and decreased cell survival. That is, the antiproliferative effects of ATRA appear to be partly mediated via ROS overproduction. More than half of the overproduction of ROS and the decrease in cell survival induced by ATRA was rescued by ATZ (Fig. 6). ATZ reportedly inactivates catalase by disrupting the $\mathrm{H} 2 \mathrm{O} 2$ binding site. ${ }^{24)}$ If the catalytic activity of catalase is inhibited by ATZ, ROS should be increased by the addition of ATZ. In the present study, contrary to our expectation, the increase in ROS induced by ATRA was decreased by ATZ. This indicates the involvement of ATZ binding site of catalase and/or its related pathways in ROS production.

Unusual behaviors of mammalian catalase have been reported recently. Vetrano et $\mathrm{al}^{25}{ }^{25}$ demonstrated that, in addition to $\mathrm{H}_{2} \mathrm{O}_{2}$ decreasing catalytic activity, mammalian catalases can function as an oxidase, using oxygen when $\mathrm{H}_{2} \mathrm{O}_{2}$ is absent or low. Endogenous substrates, including the tryptophan precursor indole, the neurotransmitter precursor $\beta$-phenylethylamine, various peroxidase and laccase substrates, and carcinogenic benzidines are oxidized by catalase or inhibit this activity. ${ }^{25)}$ ATZ at a high concentration inhibits the oxidase activity of catalase. ${ }^{25,26)}$ The ROS decrease induced by $10 \mathrm{mM}$ ATZ in the present study supports the inhibition of oxidase by ATZ (Fig. 5). Another unexpected finding related to catalase was Heck et al. ${ }^{27)}$ discovering that UVB light stimulates ROS production through the action of catalase. UVB light is absorbed by catalase and converted into reactive chemical intermediates. Chelikani et al. ${ }^{28)}$ pointed out that UVB light $(290 \sim 320 \mathrm{~nm})$ is below the Soret absorbance maximum of heme and is near the absorbance wavelength for NADPH. They suggested that this effect is due to catalase binding NADPH. Clarifying the mechanism of catalase-mediated ROS production requires investigations of the substrates for catalase oxidase activity in cells treated with ATRA. The antioxidants are in fact a redox agent, protecting against free radicals in some circumstances and promoting free radical generation in others. $^{29)}$

In conclusion, ATRA can cause ROS overproduction and catalase induction, and the elevated ROS is involved in the antiproliferative effects of ATRA in 36B10 cells.

\section{Acknowledgements}

This work was supported by the Korea Research Foundation Grant funded by the Korean Government (MOEHRD) (R052004-000-11814-0).

\section{References}

1. Wang CJ, Chou MY, Lin JK. Inhibition of growth and development of the transplantable C-6 glioma cells inoculated in rats by retinoids and carotenoids. Cancer Lett 1989;48: 135-142

2. Yung WK, Lotan $R$, Lee $P$, Lotan $D$, Steck PA. Modulation of growth and epidermal growth factor receptor activity by retinoic acid in human glioma cells. Cancer Res 1989;49:1014-1019

3. Defer GL, Adle-Biassette H, Ricolfi F, et al. All-trans retinoic acid in relapsing malignant gliomas: clinical and radiological stabilization associated with the appearance of intratumoral calcifications. J Neurooncol 1997;34:169-177

4. Kaba SE, Kyritsis AP, Conrad C, et al. The treatment of recurrent cerebral gliomas with all-trans-retinoic acid (tretinoin). J Neurooncol 1997;34:145-151

5. Phuphanich S, Scott C, Fischbach AJ, Langer C, Yung WK. All-trans-retinoic acid: a phase II Radiation Therapy Oncology Group study (RTOG 91-13) in patients with recurrent malignant astrocytoma. J Neurooncol 1997;34:193-200

6. Urbach J, Rando RR. Isomerization of all-trans-retinoic acid to 9-cis-retinoic acid. Biochem J 1994;299(Pt 2):459-465

7. Ziouzenkova O, Plutzky J. Retinoid metabolism and nuclear receptor responses: new insights into coordinated regulation of the PPAR-RXR complex. FEBS Lett 2008;582: 32-38 
8. Mangelsdorf DJ, Evans RM. The RXR heterodimers and orphan receptors. Cell 1995;83:841-850

9. Girnun GD, Domann FE, Moore SA, Robbins ME. Identification of a functional peroxisome proliferator-activated receptor response element in the rat catalase promoter. Mol Endocrinol 2002;16:2793-2801

10. Johnson P. Antioxidant enzyme expression in health and disease: effects of exercise and hypertension. Comp Biochem Physiol C Toxicol Pharmacol 2002;133:493-505

11. Shinjyo N, Kita K. Relationship between reactive oxygen species and heme metabolism during the differentiation of Neuro2a cells. Biochem Biophys Res Commun 2007;358:130135

12. Pasquali MA, Gelain DP, Zanotto-Filho A, et al. Retinol and retinoic acid modulate catalase activity in Sertoli cells by distinct and gene expression-independent mechanisms. Toxicol In Vitro 2008;22:1177-1183

13. Beers RF Jr, Sizer IW. A spectrophotometric method for measuring the breakdown of hydrogen peroxide by catalase. $J$ Biol Chem 1952;195:133-140

14. Wan XS, Zhou Z, Kennedy AR. Adaptation of the dichlorofluorescein assay for detection of radiation-induced oxidative stress in cultured cells. Radiat Res 2003;160:622-630

15. Wan XS, Zhou Z, Ware JH, Kennedy AR. Standardization of a fluorometric assay for measuring oxidative stress in irradiated cells. Radiat Res 2005;163:232-240

16. Aebi H. Catalase in vitro. Methods Enzymol 1984;105:121-126

17. Lu J, Zhang F, Zhao D, et al. ATRA-inhibited proliferation in glioma cells is associated with subcellular redistribution of beta-catenin via up-regulation of Axin. J Neurooncol 2008;87: 271-277

18. Bouterfa H, Picht T, Kess D, et al. Retinoids inhibit human glioma cell proliferation and migration in primary cell cultures but not in established cell lines. Neurosurgery 2000; 46:419-430
19. Higashida $\mathrm{H}$, Miki $\mathrm{N}$, Ito $\mathrm{M}$, Iwata $\mathrm{T}$, Tsukida $\mathrm{K}$. Cytotoxic action of retinoidal butenolides on mouse neuroblastoma and rat glioma cells. Int J Cancer 1984;33:677-681

20. Fischer I, Nolan CE, Shea TB. Effects of retinoic acid on expression of the transformed phenotype in C6 glioma cells. Life Sci 1987;41:463-470

21. Conte da Frota ML Jr, Gomes da Silva E, Behr GA, et al. All-trans retinoic acid induces free radical generation and modulate antioxidant enzyme activities in rat sertoli cells. Mol Cell Biochem 2006;285:173-179

22. Chen Y, Buck J, Derguini F. Anhydroretinol induces oxidative stress and cell death. Cancer Res 1999;59:3985-3990

23. Palozza P, Calviello G, Serini S, et al. Beta-carotene at high concentrations induces apoptosis by enhancing oxyradical production in human adenocarcinoma cells. Free Radic Biol Med 2001;30:1000-1007

24. Putnam CD, Arvai AS, Bourne Y, Tainer JA. Active and inhibited human catalase structures: ligand and NADPH binding and catalytic mechanism. J Mol Biol 2000;296:295-309

25. Vetrano AM, Heck DE, Mariano TM, Mishin V, Laskin DL, Laskin JD. Characterization of the oxidase activity in mammalian catalase. J Biol Chem 2005:280:35372-35381

26. Kirkman HN, Gaetani GF. Mammalian catalase: a venerable enzyme with new mysteries. Trends Biochem Sci 2007; 32:44-50

27. Heck DE, Vetrano AM, Mariano TM, Laskin JD. UVB light stimulates production of reactive oxygen species: unexpected role for catalase. J Biol Chem 2003;278:2243222436

28. Chelikani P, Fita I, Loewen PC. Diversity of structures and properties among catalases. Cell Mol Life Sci 2004;61: 192-208

29. Herbert V. Prooxidant effects of antioxidant vitamins. Introduction. J Nutr 1996;126:1197S-1200S 


\section{레티노인산에 의한 카타라제의 유도가 36B10세포의 증식억제에 미치는 효과}

충북대학교 의과대학 방사선종양학교실*, 건국대학교 의과대학 환경생물의학교실 ${ }^{\dagger}$

$$
\text { 박 우 윤*·유 재 } \text { 란 }^{\dagger}
$$

목 적: 레티노인산(All-trans retinoic acid, ATRA)은 뇌종양 세포의 증식을 억제한다. 최근 ATRA에 의한 카타라제의 유도가 보고된 바 있다. 이에 저자들은 ATRA의한 카타라제의 유도가 ATRA의 세포증식 억제 효과와 관련이 있는지 알아보고자 하였다.

대상 및 방법: 36B10세포를 0 50 $\mu \mathrm{M}$ ATRA로 24, 48시간 처리한 후 카타라제의 mRNA, 단백질 및 활성도를 측정 하였다. 반응성산소종(reactive oxygen species, ROS)은 2',7'-dichlorofluorescin diacetate를 사용하여 측정하였고, 세포사는 clonogenic assay로 측정하였다.

결 과: 카타라제의 mRNA, 단백질 및 활성도는 ATRA의 농도 및 처리 시간에 따라 증가하였다. ATRA에 의해 증가 한 카타라제의 활성도는 3-amino-1,2,4-triazole (ATZ)에 의해 감소하였다. ATRA에 의해 증가한 ROS는 ATZ에 의 해 감소하였다. ATRA에 의해 감소한 세포 생존분획은 ATZ에 의해 부분적으로 증가하였다.

결 론: ATRA에 의해 유도된 카타라제는 ROS의 과생산과 관련 있으며 이는 36B10세포의 증식 억제를 가져온다.

핵심용어: 레티노인산, 카타라제, 반응성산소종 